\title{
Evaluation of Arbuscular Mycorrhizal Fungi of Orchard Soils for Growth Improvement in Maize under Protected Conditions
}

\author{
Baby Summuna $^{1}$, P.A. Sheikh ${ }^{1}$ and Tahmina Mushtaq ${ }^{2} *$ \\ ${ }^{1}$ Division of Plant Pathology, S.K. University of Agricultural Sciences and Technology of \\ Kashmir, Shalimar, Srinagar-190025 Jammu and Kashmir, India \\ ${ }^{2}$ Division of Entomology, S.K. University of Agricultural Sciences and Technology of Kashmir, \\ Shalimar, Srinagar-190025 Jammu and Kashmir, India \\ *Corresponding author
}

\begin{tabular}{|c|c|}
\hline & A B S T R A C T \\
\hline & \multirow{6}{*}{$\begin{array}{l}\text { An experiment was conducted to determine the effect of arbuscular mycorrhiza fungal } \\
\text { (AMF) isolates on various growth parameters and enzymatic activity in maize grown } \\
\text { under protected conditions. One hundred and eight AMF isolates, collected from apple, } \\
\text { pear and cherry rhizosphere, were chosen to assess their efficiency in improving growth of } \\
\text { maize cv. "C6". The plant height, root biomass, shoot biomass, root mycorrhizal } \\
\text { colonization and root and shoot phosphatase in AMF inoculated maize plants ranged from } \\
16.0 \text { to } 27.9 \mathrm{~cm}, 2.75 \text { to } 4.60 \mathrm{~g}, 9.37 \text { to } 14.26 \mathrm{~g}, 17.78 \text { to } 65.15 \%, 3.59 \text { to } 40.66 \mathrm{~m} \text { moles } \\
\mathrm{PNP} / \mathrm{g} \text { fresh root weight and } 3.20 \text { to } 30.73 \mathrm{~m} \text { moles PNP/g soil, respectively, as compared } \\
18.1 \mathrm{~cm}, 3.25 \mathrm{~g}, 10.74 \mathrm{~g}, 0 \%, 3.66 \mathrm{~m} \text { moles PNP/g fresh weight and } 3.33 \mathrm{~m} \text { moles PNP/g } \\
\text { soil in control. The AMF isolates collected from different hosts, revealed variable } \\
\text { behaviour with respect to plant growth improvement and enzyme activities. The AMF } \\
\text { isolates showed almost similar pattern with a little variation. The AMF isolates of cherry, } \\
\text { apple and pear rhizosphere showed } 23.2 \text { to } 65.2 \text {, } 19.8 \text { to } 53.1 \text { and } 17.8 \text { to } 61.5 \% \text { root } \\
\text { colonization, respectively. On the basis of initial screening twenty most efficient isolates } \\
\text { were compared statistically which showed significant increase of } 7.0 \text { to } 54.6,12.6 \text { to } 41.5 \\
\text { and } 11.7 \text { to } 32.8 \% \text { in plant height, root biomass and shoot biomass, respectively, in maize. }\end{array}$} \\
\hline & \\
\hline $\begin{array}{l}\text { Maize, Phosphatase } \\
\text { activity, Root } \\
\text { colonization, } \\
\text { AMF fungi. }\end{array}$ & \\
\hline Article Info & \\
\hline $\begin{array}{l}\text { Accepted: } \\
\text { 20 February } 2017 \\
\text { Available Online: } \\
10 \text { March } 2017\end{array}$ & \\
\hline & \\
\hline
\end{tabular}

\section{Introduction}

In natural ecosystems arbuscular mycorrhizal fungi (AMF) form regular component of rhizosphere microflora and are desirable for sustainable plant-soil system as they establish symbiotic associations with most of the terrestrial plants (Sharma et al., 2009). AMF inhabit a variety of ecosystems including agriculture lands, forest, grasslands and many stressed environments. They colonize roots of most plants including bryophyte, pteridophyte, gymnosperms and angiosperms
(Wang and Zao, 2008). The mycorrhizal association helps the host plants in overcoming several biotic and abiotic stresses and improves plant growth. Robinson et al., (2014) reported increased plant height, root length, shoot length, root biomass and shoot biomass in berseem plants due to AMF inoculation. Several AM fungi namely Glomus fasciculatum, $G$. mosseae, $G$. macrocarpum and Sclerocystis dussii were screened by Dutt et al., (2013) in apricot 
(Prunus armeniaca L.) cv. 'New Castle' seedlings for vegetative growth performance in soil supplemented with $0,25,50$ and $100 \mathrm{mg} \quad \mathrm{P} \quad \mathrm{kg}^{-1}$ soil. G. fasciculatum inoculation gave significantly higher spore count and better root colonization and showed improvement in growth characteristics and leaf nutrient status over uninoculated control. The soil inoculation of G. fasciculatum + $50 \mathrm{mg} \mathrm{P} \mathrm{kg}$ application was found most effective with corresponding values $(209,59$, 102.2, 86, 57.6, 70.8 and 131.5\%) for higher spore count, root colonization, seedling height, stem diameter, dry weight of shoot and root and leaf area, respectively. Veerabhadraswamy and Garampalli (2011) found enhanced plant growth due to AM fungi (Glomus fasciculatum, G. mosaea and Acaulospora laevis). Several species of mycorrhizal fungi increased plant biomass in maize (Othira et al., 2012). Li et al., (2012) demonstrated that AMF communities increased plant height, shoot dry weight, root dry weight, and leaf area in cucumber. Mathew et al., (2003) achieved significant increase in height of banana cultivars during all growth stages, reaching a final height of $16.76 \mathrm{~cm}$ which was $60.7 \%$ higher than uninoculated control. Sharma et al., (2012a, b) found significant correlation between roots mycorrhizal root colonization and tree diameter/yield in apple cv. 'Royal Delicious'. AMF form their extended hyphal network which from nutrient-poor soils efficiently absorb and translocate water and mineral nutrients to its host (Ryan and Angus, 2003). AMF have positive effect on root longevity by increasing the lignification of plant cell walls which protects roots against infection by soil borne pathogens (Harrier and Watson, 2004). Besides, AMF induce higher photosynthetic efficiency and tolerance in plants against abiotic stresses such as drought, soil compaction salinity or cold, etc. (Auge, 2000; Hildebrandt et al., 2007; Miransari, 2010; Wu et al., 2013). Utkhede and Smith
(2000) reported that Glomus intraradices enhanced plant growth and fruit yield in apple trees planted in soils conducive to replant disease. AMF are the main component of soil microbial population in most agroecosystems and form a close association with more than $80 \%$ plant species and render immobilized mineral nutrients available to the plants so as to sustain normal growth and reproduction (Bordoloi et al., 2015). The present study was aimed to evaluate the efficacy of various AMF isolates, collected from apple, pear and cherry rhizosphere, in maize grown under protected conditions in Kashmir.

\section{Materials and Methods}

Arbuscular mycorrhizae were isolated during active growth period from apple, pear and cherry orchard soils of Kashmir valley as per wet sieving and decantation method (Gerdman and Nicolson, 1963). These AMF isolates were identified and multiplied on maize plants under polyhouse conditions. For raising maize plants, first growth medium was prepared by mixing sterilized soil and sand in 2:1 (w/w) ratio (Bhardwaj et al., 2000). The soil and sand was sterilized at $1.5 \mathrm{~kg} / \mathrm{m}^{3}$ for one hour for three consecutive days. The growth medium was filled in polybags of 1.5 $\mathrm{kg}$ capacity. Apparently healthy maize seeds cv. 'C-6' were surface sterilized with $0.5 \%$ sodium hypochlorite and germinated on petriplates under aseptic conditions. Two seeds were sown per polybag and inoculated with 50 spores of each AMF isolate individually at a soil depth of $5 \mathrm{~cm}$. Uninoculated control polybags were also maintained. For each isolate three replications were maintained and kept in a greenhouse at $30 \pm 1^{\circ} \mathrm{C}$ in a completely randomized design. The maize plants in polybags were irrigated as and when required. The plants were uprooted 45 days after sowing and checked microscopically for the presence of AMF spores. The spores of AMF isolates were characterized on the basis 
of their morphological characters i.e. shape, size, colour and ornamentation, type of hyphal attachment, spore wall characters, etc. Such examinations were made under a compound microscope (Olympus U-CTR-302). Spore identification was done according to Schenck and Perez (1987) and also by comparison with the authentic literature/standard monographs (INVAM, 2005; Schenck and Perez, 1990; Morton and Redecker, 2001; Schubler and Walker, 2010).

AM fungal isolates were evaluated on the basis of plant growth improvement and soil and root phosphatase activity. Maize plants cv. 'C-6' were grown in polybags $(1.5 \mathrm{~kg}$ capacity) maintained under polyhouse conditions and inoculated with test AMF fungal spores. Four replications were maintained for each isolate in a completely randomized design. Various plant growth parameters viz., dry root and shoot biomass, plant height and root colonization and enzyme activity of roots and soil (acid phosphatase) were recorded 45 days after the inoculation. For assessing mycorrhizal colonization, fresh maize roots were collected and thoroughly washed with distilled water to remove the adhering soil. The washed roots were cut into small bits of $1 \mathrm{~cm}$ size and placed in $10 \%$ $\mathrm{KOH}$. Later the roots were rinsed with dilute $\mathrm{HCl}(2 \%)$ and boiled for 5 minutes in cotton blue stain followed by overnight destaining in lactophenol. The roots were examined under stereomicroscope (Olympus SZ-61) and infectivity with AM fungi proved by observing the presence of arbuscules, vesicles, Hartig net and hyphae of endophytes on maize roots, if any. Root segments were mounted on glass slide with lactophenol and observed under compound microscope (Olympus U-CTR-30-2). A minimum of 150 segments for each sample were observed for the assessment of mycorrhizal infection as per the formula of Biermann and Lindermann (1981).

$\begin{aligned} & \text { Per cent } \\ & \text { mycorrhizal } \\ & \text { infection }\end{aligned}=\frac{\begin{array}{l}\text { Number of infected } \\ \text { root segments }\end{array}}{\begin{array}{l}\text { Total number of } \\ \text { segments examined }\end{array}} \times 100$

Acid phosphatase activity of roots and soil was estimated as per method of Tabatabai and Bremner (1969) and expressed in terms of milli moles PNP/g fresh wt. root and milli moles $\mathrm{PNP} / \mathrm{g}$ soil respectively.

\section{Statistical analysis}

The data was analyzed by using analysis of variance technique as per Gomez and Gomez (1983). Wherever necessary the data prior to analysis was appropriately transformed using arc-sine transformation to fulfill the assumption of normality.

\section{Results and Discussion}

The AMF isolates from four districts varied in their impact on maize plant growth, mycorrhizal colonization and phosphatase activities in root and soil (Table 1). Districtwise AMF isolates showed almost similar trend in improving the plant growth. The plant height in AMF inoculated plants, in general, ranged from 16.0 to $27.9 \mathrm{~cm}$ as compared to $18.1 \mathrm{~cm}$ in uninoculated control. The root biomass varied from 2.75 to $4.60 \mathrm{~g}$ as compared to $3.25 \mathrm{~g}$ in control. The shoot biomass ranged from 9.37 to $14.26 \mathrm{~g}$ in comparison to $10.74 \mathrm{~g}$ in control. The root mycorrhizal colonization in inoculated plants varied from 17.78 to $65.15 \%$. The root phosphatase in AMF inoculated plants was in the range of 3.59 to $40.66 \mathrm{~m}$ moles $\mathrm{PNP} / \mathrm{g}$ fresh root weight in comparison to $3.66 \mathrm{~m}$ moles PNP/g fresh weight in control. The shoot phosphatase in AMF inoculated plants varied from 3.20 to $30.73 \mathrm{~m}$ moles $\mathrm{PNP} / \mathrm{g}$ soil as compared to $3.33 \mathrm{~m}$ moles $\mathrm{PNP} / \mathrm{g}$ soil in control. 
The AMF isolated from different host viz., apple, pear and cherry rhizosphere, and evaluated on maize revealed variable behaviour with respect to plant growth improvement and enzyme activities (Table 2). Crop-wise AMF isolates showed almost similar pattern with a little variation. The plant height, in general, was in the range of $15.50-27.93 \mathrm{~cm}$ as compared to $18.06 \mathrm{~cm}$ in control. The root biomass varied from 2.75 $4.60 \mathrm{~g}$ in AMF inoculated plants as compared to $3.25 \mathrm{~g}$ in uninoculated control.

The shoot biomass ranged from 9.37 to 14.26 $\mathrm{g}$ in AMF inoculated plants as compared to $10.74 \mathrm{~g}$ in uninoculated control. Mycorrhizal root colonization in inoculated plants was in the range of 17.78 to $65.15 \%$. The root colonization by AMF isolates from cherry, apple and pear rhizosphere was 23.2-65.2, 19.8-53.1 and $17.8-61.5 \%$, respectively. The root phosphatase was in the range of 3.30$40.66 \mathrm{~m} \mathrm{~mol} \mathrm{PNP} / \mathrm{g}$ fresh root weight as compared to $3.66 \mathrm{~m} \mathrm{~mol} \mathrm{PNP/g}$ fresh root weight in control. The soil phosphatase activity varied from 3.23-30.73 m mole PNP /g soil in AMF inoculated plants as compared to uninoculated control.

On the basis of initial screening, twenty most efficient isolates were compared statistically (Table 3). The efficient isolates identified were Glomus geosporum, G. diaphanum, $G$. versiforme, G. boreale, G. glomerulatum, G. sinuоsum, G. macrocarpum, $G$. heterosporum, Acaulospora rehmii, A. bireticulata, A. laevis, A. longula, Acaulospora spp., Septoglomus deserticola, Gigaspora decipiens, Funneliformis verrucolosum and Scutellospora armeniaca.

Of these, the most efficient 20 AMF isolates compared statistically revealed significant increase of 7.0 to $54.65,12.6$ to 41.5 and 11.7 to $32.8 \%$ in plant height, root biomass and shoot biomass, respectively, in maize. Further, mycorrhizal root colonization and root and soil phosphatase activities in AMF inoculated plants ranged from 23.7 to $65.2 \%$, 3.6 to $40.7 \mathrm{~m}$ moles PNP/g fresh root weight and 5.7 to $30.7 \mathrm{~m}$ moles $\mathrm{PNP} / \mathrm{g}$ soil, respectively.

Table.1 Effectiveness of AMF isolates isolated from various districts on growth and enzyme activity of maize

\begin{tabular}{lcccccc}
\hline District & $\begin{array}{c}\text { Plant height } \\
(\mathbf{c m})\end{array}$ & $\begin{array}{c}\text { Mycorrhizal } \\
\text { colonization } \\
(\boldsymbol{\%})\end{array}$ & $\begin{array}{c}\text { Root } \\
\text { biomass } \\
(\mathbf{g})\end{array}$ & $\begin{array}{c}\text { Shoot } \\
\text { biomass }(\mathbf{g})\end{array}$ & $\begin{array}{c}\text { Root } \\
\text { phosphatase } \\
\text { (milli moles } \\
\text { PNP/g fresh } \\
\text { wt. root) }\end{array}$ & $\begin{array}{c}\text { Soil } \\
\text { phosphatase } \\
\text { (milli moles } \\
\text { PNP/g soil) }\end{array}$ \\
\hline Srinagar & $16.26-27.93$ & $17.78-65.15$ & $2.75-4.60$ & $9.37-14.26$ & $3.59-40.66$ & $3.20-30.73$ \\
Ganderbal & $16.03-26.33$ & $20.83-61.53$ & $2.80-4.53$ & $9.89-14.22$ & $3.73-40.60$ & $6.30-30.65$ \\
Shopian & $16.00-25.20$ & $19.84-50.84$ & $2.77-4.25$ & $9.64-14.16$ & $6.34-38.50$ & $3.46-27.66$ \\
Baramulla & $16.33-25.20$ & $19.84-50.73$ & $2.76-4.27$ & $9.77-14.18$ & $3.66-39.53$ & $3.23-27.86$ \\
Control & $18.06 \pm 0.03$ & $0.00 \pm 0.00$ & $3.25 \pm 0.01$ & $10.74 \pm 0.01$ & $3.66 \pm 0.33$ & $3.33 \pm 0.33$ \\
\hline
\end{tabular}


Table.2 Effectiveness of AMF isolates isolated from the rhizosphere of various horticultural crops on growth and enzyme activity of maize

\begin{tabular}{lcccccc}
\hline Crop & $\begin{array}{c}\text { Plant height Mycorrhizal } \\
(\mathbf{c m})\end{array}$ & $\begin{array}{c}\text { Root } \\
\text { colonization } \\
(\boldsymbol{\%})\end{array}$ & $\begin{array}{c}\text { biomass } \\
\mathbf{( g )}\end{array}$ & $\begin{array}{c}\text { Shoot } \\
\text { biomass } \\
(\mathbf{g})\end{array}$ & $\begin{array}{c}\text { Root } \\
\text { phosphatase } \\
\text { (milli } \\
\text { molesPNP/g } \\
\text { fresh wt. root) }\end{array}$ & $\begin{array}{c}\text { Soil } \\
\text { phosphatase } \\
\text { (milli moles } \\
\text { PNP/g soil) }\end{array}$ \\
\hline Apple & $15.50-26.90$ & $19.84-53.14$ & $2.75-4.54$ & $9.37-14.26$ & $3.60-40.63$ & $3.52-29.66$ \\
Pear & $16.26-26.33$ & $17.78-61.53$ & $2.77-4.41$ & $10.37-14.21$ & $7.76-40.60$ & $3.73-28.83$ \\
Cherry & $17.03-27.93$ & $23.19-65.15$ & $2.76-4.60$ & $10.20-14.24$ & $3.62-40.66$ & $3.23-30.73$ \\
$\begin{array}{l}\text { Control } \\
\text { (uninoculated) }\end{array}$ & $18.06 \pm 0.03$ & $0.00 \pm 0.00$ & $3.25 \pm 0.01$ & $10.74 \pm 0.01$ & $3.66 \pm 0.33$ & $3.33 \pm 0.33$ \\
\hline
\end{tabular}

Table.3 Most efficient AMF isolates showing improvement in growth parameters and soil phosphatase activity on maize

\begin{tabular}{|c|c|c|c|c|c|c|c|}
\hline $\begin{array}{l}\text { S. } \\
\text { No. }\end{array}$ & AMF species/genera & $\begin{array}{c}\text { Plant } \\
\text { height } \\
(\mathrm{cm})\end{array}$ & $\begin{array}{c}\text { Mycorrhizal } \\
\text { colonization } \\
(\%)\end{array}$ & $\begin{array}{c}\text { Root } \\
\text { biomass } \\
\text { (g) }\end{array}$ & $\begin{array}{c}\text { Shoot } \\
\text { biomass } \\
\text { (g) }\end{array}$ & $\begin{array}{c}\text { Root } \\
\text { phosphatase } \\
\text { (millimoles } \\
\text { PNP/g fresh } \\
\text { wt. of root }\end{array}$ & $\begin{array}{c}\text { Soil } \\
\text { phosphatase } \\
\text { (millimoles } \\
\text { PNP/g soil) }\end{array}$ \\
\hline 0. & Control & 18.06 & 0.00 & 3.25 & 10.74 & 3.66 & 3.33 \\
\hline 1. & Glomus geosporum & 27.93 & 65.15 & 4.56 & 14.24 & 40.66 & 30.73 \\
\hline 2. & Acaulospora rehmii & 27.33 & 53.67 & 4.60 & 14.23 & 40.65 & 29.76 \\
\hline 3. & Glomus diaphanum & 26.90 & 53.14 & 4.54 & 14.26 & 40.63 & 29.66 \\
\hline 4. & Gegaspora decipiens & 26.33 & 61.53 & 4.41 & 14.21 & 40.6 & 28.83 \\
\hline 5. & Acaulospora bireticulata & 25.23 & 52.19 & 4.53 & 14.22 & 40.57 & 30.66 \\
\hline 6. & Septoglomus deserticola & 25.23 & 38.26 & 2.85 & 10.57 & 39.53 & 27.86 \\
\hline 7. & Glomus versiforme & 25.23 & 23.19 & 2.99 & 14.20 & 3.59 & 9.33 \\
\hline 8. & Glomus boreale & 25.20 & 38.84 & 4.23 & 14.15 & 38.46 & 15.69 \\
\hline 9. & Acaulospora spp. & 25.20 & 34.99 & 3.29 & 12.54 & 24.07 & 14.33 \\
\hline 10. & G. glomerulatum & 24.23 & 31.95 & 3.13 & 11.60 & 16.53 & 8.66 \\
\hline 11. & Glomus macrocarpum & 24.23 & 49.92 & 4.18 & 14.10 & 25.1 & 16.26 \\
\hline 12. & Acaulospora spp. & 24.23 & 50.12 & 3.65 & 13.96 & 26.12 & 16.16 \\
\hline 13. & Glomus heterosporum & 24.20 & 33.34 & 3.93 & 9.48 & 30.6 & 21.27 \\
\hline 14. & Acaulospora laevis & 24.03 & 41.13 & 3.80 & 13.78 & 7.76 & 19.75 \\
\hline 15. & Acaulospora spp. & 23.40 & 29.74 & 4.10 & 11.43 & 34.79 & 5.73 \\
\hline 16. & Glomus sinuosum & 23.40 & 40.84 & 2.99 & 14.01 & 10.34 & 6.66 \\
\hline 17. & $\begin{array}{l}\text { Funneliformis } \\
\text { verrucolosum }\end{array}$ & 23.73 & 49.11 & 4.12 & 13.63 & 30.56 & 23.86 \\
\hline 18. & Scutellospora armeniaca & 23.76 & 49.31 & 4.13 & 11.99 & 30.44 & 24.66 \\
\hline 19. & Acaulospora longula & 23.10 & 27.25 & 2.93 & 10.85 & 3.62 & 9.66 \\
\hline 20. & Glomus boreale & 22.86 & 23.75 & 2.84 & 13.60 & 17.7 & 8.46 \\
\hline \multicolumn{2}{|c|}{$C D(p \leq 0.05)$} & 0.35 & 2.89 & 0.16 & 0.36 & 3.12 & 2.12 \\
\hline
\end{tabular}


Plate.1 (I) Intraradical AMF fungal hyphae and spores in host (maize) root tissue; (II) Extramatrical AMF fungal hyphae
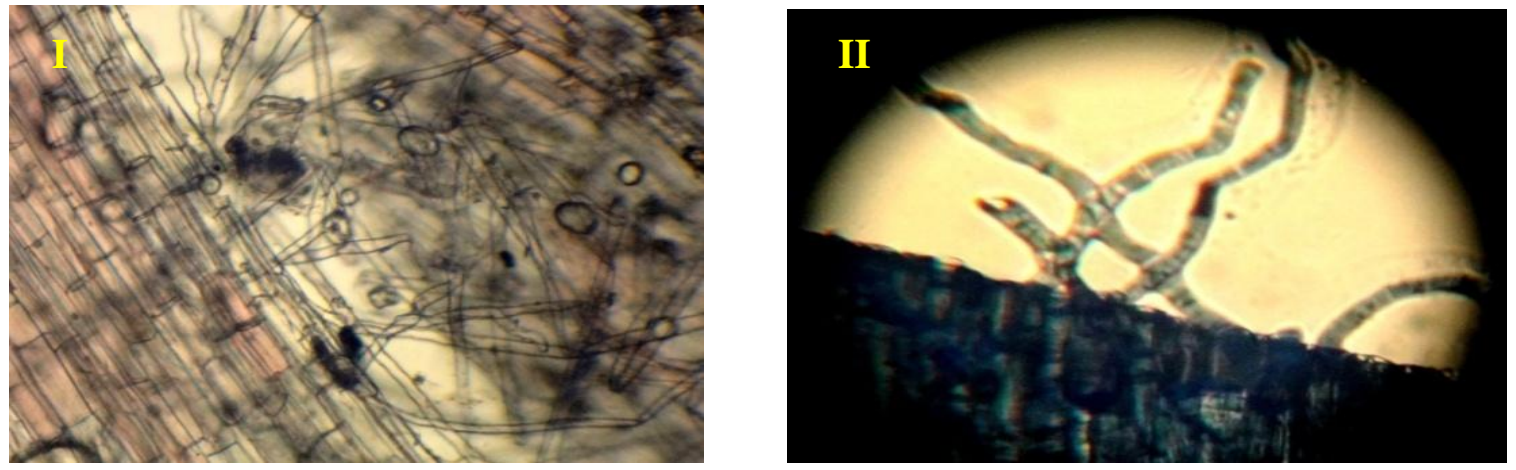

Plate.2 Maize roots showing arbuscules and vesicles

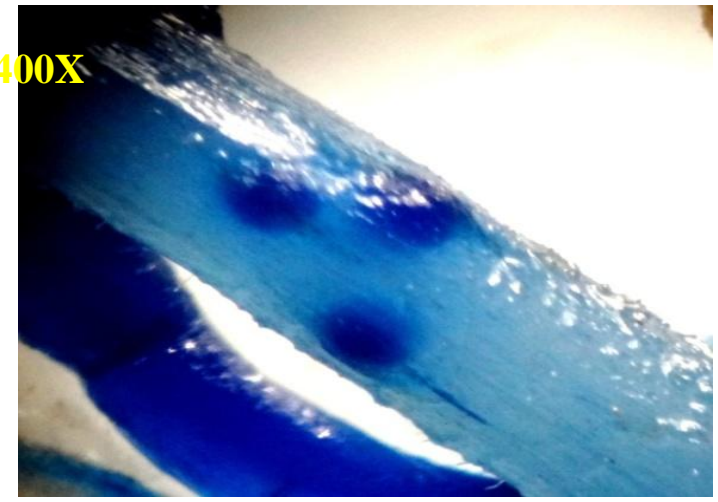

Perusal of data on root biomass revealed that A. rehmii, G. geosporum, G. diaphanum and A. bireticulata were statistically at par with one another and significantly superior over all other species evaluated. Maximum and minimum root biomass 4.60 and of $2.84 \mathrm{~g}$ was observed in $A$. rehmii and $G$. boreale, respectively (Table 3). Perusal of Table 1 revealed maximum and minimum shoot biomass of 14.26 and $9.48 \mathrm{~g}$ in $G$. diaphanum and $G$. heterosporum, respectively. $G$. diaphanum), G. geosporum, A. rehmii, Gigaspora decipiens, A. bireticulata, $G$. versiforme, G. boreale and G. macrocarpum were statistically at par with one another but superior over other isolates (Table 3). Maximum root phosphatase activity was observed in G. geosporum (40.66 m moles $\mathrm{PNP} / \mathrm{g}$ fresh root weight) but was at par with A. rehmii, $G$. diaphanum, $G$. decipiens, A.

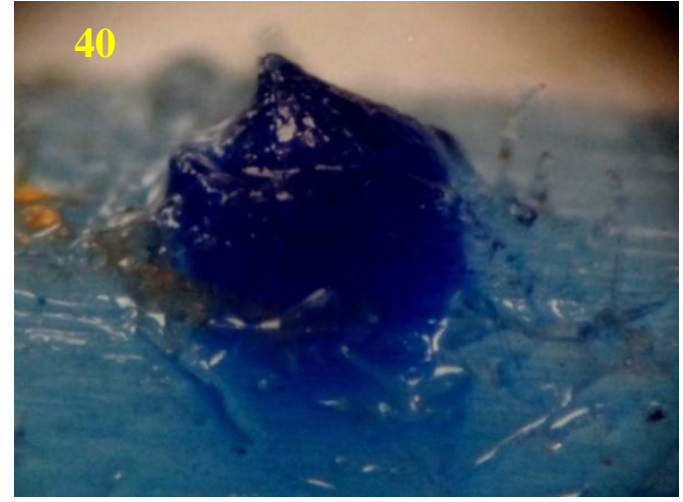

bireticulata, S. desrticola and G. boreale. $G$. versiforme showed a minimum root phosphatase activity of $3.59 \mathrm{~m}$ moles $\mathrm{PNP} / \mathrm{g}$ fresh root weight though at par with Acaulospora longula (Table 3). Maximum soil phosphatase activity of $30.73 \mathrm{~m}$ moles $\mathrm{PNP} / \mathrm{g}$ soil was observed in G. geosporum which was statistically at par with Acaulospora rehmii, G. diaphanum, $G$. decipiens and A. bireticulata. G. sinuosum showed minimum soil phosphatase activity of $6.66 \mathrm{~m}$ moles PNP/g soil (Table 3).

The plant height, root biomass, shoot biomass, mycorrhizal colonization, root phosphatase and shoot phosphatase in AMF inoculated maize plants generally was higher in comparison to the uninoculated control. District-wise AMF isolates showed almost similar trend in improving the plant growth. 
Trindade et al., (2006) noticed 33 AMF fungal species in the agrosystems of coffee, fruits and annual crops in Brazil and reported Acaulospora species as the most frequently encountered species in the soils having $\mathrm{pH} 6.5$ or less. Further, they observed that certain species like Gigaspora margarita exhibited highest frequencies in aluminium rich soils. Similarly, Cuenca and Meneze (1996) during the survey of cacao plantations and nurseries in Venezuela observed 15 AMF fungal species and found species richness and diversity inversely correlated with available soil phosphorus.

In present study, the AMF inoculated plants, except a few AMF species, showed remarkable improvement in shoot biomass as well as in plant height as compared to uninoculated control. Of these, the most efficient 20 AMF isolates compared statistically revealed significant increase of 7.0 to $54.65,12.6$ to 41.5 and 11.7 to $32.8 \%$ in plant height, root biomass and shoot biomass, respectively, in maize. Further, mycorrhizal root colonization and root and soil phosphatase activities in AMF inoculated plants ranged from 23.7 to $65.2 \%, 3.6$ to 40.7 $\mathrm{m}$ moles $\mathrm{PNP} / \mathrm{g}$ fresh root weight and 5.7 to $30.7 \mathrm{~m}$ moles $\mathrm{PNP} / \mathrm{g}$ soil, respectively. Our results are in conformity with Mehboob and Vyas (2013) who reported 52-78\% increase in mycorrhizal colonization in Trigonella foenumgreacum crop by inoculation of different AMF species. The gains in plant growth and development appear due to better root colonization and improvement in rhizosphere activities. The results are in agreement with Veerabhadraswamy and Garampalli (2011) who reported significant increase in dry weight and plant height in mycorrhizal maize plants due to high degree of fungal colonization in treated plants as compared to non-mycorrhizal ones. High degree of mycorrhizal colonization reflects better proliferation and wide hyphal network in rhizosphere which, in turn, ensures better nutrient acquisition and transport to host plant thereby resulting in significant stimulation of aerial growth (Hamza et al., 2010). Kabir and Koide (2000) also observed higher shoot dry weight of maize plants due to higher mycorrhizal colonization and higher phosphorus content. Our findings are in agreement with Tabasum et al., (2012) who reported improved growth of leguminous plants by AM fungi due to enhancement of phosphate uptake by mycorrhizal plants. In present study, the percentage of root colonization was higher in mycorrhizal than non-mycorrhizal plants. Glomus geosporum proved significantly superior in increasing mycorrhizal colonization ability of isolates over all other species tested showing $65.15 \%$ colonization, followed by Gigaspora decipiens with $61.53 \%$ colonization. Tanvir et al., (2011) reported variations in AMF root colonization in various members of Lamiaceae. Different edapho-climatic factors like soil type, nutritional status, $\mathrm{pH}$, organic matter, moisture, rain fall, temperature, etc. may be responsible for variations in root colonization and spore population (Sharma et al., 1986). Our findings are favoured by various workers who reported that root colonization of AMF is genetically controlled (Raju et al., 1990). The effects of colonization by mycorrhizal fungi on growth and nutrient contents have also been reported for many other plants, such as basil [Ocimum basilicum] (Copetta et al., 2006; RasouliSadaghiani et al., 2010). Extramatrical hyphae produced by AM fungi act as extensions of roots and increase the surface area of root system, making it more efficient for the absorption of water and diffusion of limited nutrients (Bagyaraj and Reddy, 2000). G. etunicatum inoculated mint and oregano (Origanum vulgare) plants had increased growth and nutrient contents (Karagiannidis et al., 2012). The positive effect of AMF root colonization by $G$. mosseae on shoot biomass 
of oregano plants raised in greenhouse has also been reported by Khaosaad et al., (2006). Sharma et al., (1998) found highest root colonization of $16 \%$ in apple crop in Manali and lowest in Kotgarh region.

Initial screening revealed Glomus geosporum, Acaulospora rehmii, Glomus diaphanum, Gigaspora decipiens and A. bireticulata to be significantly superior in improving maize plant growth and soil nutrient availability viz$a-v i z$ phosphatase enzyme activity. Othira et al., (2012) reported increased plant height and biomass in maize due to the inoculation of several species of mycorrhizal fungi and found Glomus spp. as the most efficient isolates. Further, they attributed the variable growth efficacy of AMF isolates to the differences in their effectiveness to colonize plant roots and their ability to grow in soil, thereby enhancing nutrient mobilization and uptake. Increase in root and shoot weight have also been reported in Cucurbita pepo (Colla et al., 2007), Lotus glaber (Sannazzaro et al., 2006) and soybean (Sharifi et al., 2007). Our work is also in line with Feng et al., (2002) and (Tian et al., 2004) who reported significant increase in shoot biomass in cotton plants inoculated due to G. mosseae. Mycorrhization allows the plant to have a high root: shoot ratio causing better hydromineral nutrition and thereby reinforcing the capacity to resist stress (Caravaca et al., 2003). Acid phosphatases are considered to be important in the phosphate metabolism of the fungus. The results of present study revealed that AMF inoculated plants show higher enzyme activity than uninoculated plants. Maximum root phosphatase activity (40.66 m moles PNP/g fresh root weight) and soil phosphatase activity $(30.73 \mathrm{~m}$ moles $\mathrm{PNP} / \mathrm{g}$ soil) was observed in $G$. geosporum inoculation treatments. Our findings are in agreement with Song et al., (2001) who observed that AMF increased soil acid phosphatase activities in rhizosphere and found phosphorus sources influenced soil phosphatase activity. Ramakrishnaiah and Vijaya (2013) have reported that acid phosphatases of AMF inoculated soils are significantly influenced by the presence of AM fungi in rhizosphere of Stevia rebaudiana. The phosphatase enzyme activity is a physiological characteristic related to plant efficiency in relation to phosphorus acquisition and utilization, and is genetically variable (Tadano et al., 1993). Plants usually secrete root acid phosphatases when phosphorus availability is low; however, plant species differ in secretion ability and enzyme activity (Yan et al., 2001).

\section{References}

Auge, R.M. 2000. Stomatal behavior of arbuscular mycorrhizal plants. pp 201237. In: Arbuscular mycorrhizas: Physiology and function (eds. Y. Kapulnik and D.D. Douds.) Kluwer Acad. Publ., Dordrecht, the Netherlands.

Bagyaraj, D.J. and Reddy, B.J.D. 2000. Arbuscular mycorrhizas in sustainable agriculture. In: Microbial biotechnology for sustainable development and productivity. (Ed., Rajak, R.C.) Scientific Pub., Jodhpur, India, pp. 43-53.

Bhardwaj, L.N., Nag, N. and Sharma, S.K. 2000. Effect of VAM fungi in combination with green amendments on the management of root rot of apple. Plant Dis. Res., 15: 53-59.

Biermann, B. and Lindermann, R.G. 1981. Quantifying vesicular-arbuscular mycurrhizae: A proposed method towards standardization. New Phytopathol., 87: 63-67.

Bordoloi, A., Nath, P.C. and Shukla, A.K. 2015. Distribution of arbuscular mycorrhizal fungi associated with different land use systems of Arunachal Pradesh of Eastern Himalayan region. World J. Microbiol. Biotechnol., ISSN: 0959-3993 (Print) 1573-0972 (Online).

Caravaca, F., Diaz, E., Barea, J.M., Azcon- 
Aguilar, C. and Roldan, A. 2003. Photosynthetic and transpiration rates of Olea europaea subsp. Sylvestris and Rhannus lycioides as affected by water deficit and mycorrhiza. Biol. Plant, 46: 637-639.

Colla, G., Rouphael, Y., Cardarelli, M.T., Tullio, M., Rivera, C.M. and Rea, E. 2007. Alleviation of salt stress by arbuscular mycorrhaizal in zucchini plants grown at low and high phosphorus concentration. Biol. Fert. Soils, pp 1-9.

Copetta, A., Lingua, G. and Berta, G. 2006. Effects of three AM fungi on growth, distribution of glandular hairs and essential oil production in Ocimum basilicum L. var. Genovese. Mycorrhiza, 16:485-494.

Cuenca, G. and Meneze, E. 1996. Diversity patterns of arbuscular mycorrhizal fungi associated with cacao in Venezuela. Plant Soil, 183: 315-322.

Dutt, S., Sharma, S.D. and Kumar, P. 2013. Inoculation of apricot seedlings with indigenous arbuscular mycorhhizal fungi in optimum phosphorus fertilization for quality growth attributes. J. Plant Nutr., 36: 15-31.

Feng, G., Zhang, F.S., Li, X.L., Tian, C.Y., Tang, C. and Rengel, Z. 2002. Improved tolerance of maize plants to salt stress by arbuscular mycorrhiza is related to higher accumulation of soluble sugars in roots. Mycorrhiza, 12: 185-190.

Gerdemann, J.W. and Nicolson, T.H. 1963. Spores of mycorrhizal Endogoene species extracted from soil by wet sieving and decanting. Trans. Brit. Mycol. Soc., 46: 235-244.

Gomez, A.K. and Gomez, A.A. 1983. Statistical Procedures for Agricultural Research. John Willey and Sons, New York, USA.

Hamza, A.M., Beddiar, A., Gollotte, A., Lemoine, M.N., Kusgala, C. and Gianinazzi, S. 2010. Arbuscular mycorrhizal fungi improve the growth of olive trees and their resistance to transplantation stress. Afr. J. Biotech., 9: 1159-1167.
Harrier, L.A. and Watson, C.A. 2004. The potential role of arbuscular mycorrhizal (AM) fungi in the bioprotection of plants against soilborne pathogens in organic and/or other sustainable farming systems. Pest Manag. Sci., 149-157. [DOI: 10.1002/ps.820]

Hildebrandt, U., Regvar, M. and Bothe, H. 2007. Arbuscular mycorrhiza and heavy metal tolerance. Phytochem., 68: 139146.

INVAM. 2005. International Culture Collection of Vesicular Arbuscular Mycorrhizal Fungi. Available at http://invam.caf.wvu.edu/fungi/taxonomy /species ID. htm.

Kabir, Z. and Koide, R. 2000. The effect of dandelion or a cover crop on mycorrhiza inoculum potential, soil aggregation and yield of maize. Agri. Ecosystems and Environ., 78: 167-174.

Karagiannidis, N., Thomidis, T., PanouFilotheou, E. and Karagiannidou C. 2012. Response of three mint and two oregano species to Glomus etunicatum inoculation. Aust. J. Crop Sci., 6(1): 164169.

Khaosaad, T., Vierheilig, H., Nell, M., ZitterlEglseer, K. and Novak, J. 2006. Arbuscular mycorrhiza alter the concentration of essential oils in oregano (Origanum sp., Lamiaceae). Mycorrhiza, 15: 443-446.

Li, Y., Chen, Y.L., Li, M., Lin, X.G. and Liu, R.J. 2012. Effects of arbuscular mycorrhizal fungi communities on soil quality and the growth of cucumber seedlings in a greenhouse soil of continuously planting cucumber. Pedosphere 22: 79-87.

Mathews, D., Hegde, R.V. and Sreenivasa, M.N. 2003. Influence of Arbuscular Mycorrhizae on the vigour and growth of micro-propogated banana plantlets during acclimatization. Karn. J. Agri. Sci. 16: 438-442.

Mehboob, V.A. 2013. Diversity of AM fungi in rhizosphere of Trigonella foenumGreacum in Western Rajasthan. Inter. J. 
Plant, Anim. Environ. Sci.1: 38-43.

Miransari, M. 2010. Contribution of arbuscular mycorrhize symbiosis to plant growth under different types of soil stress. Plant Biol. 12: 563-569.

Morton, J. B. and Redecker, D. 2001. Two new families of Glomales, Archaeosporaceae and Paraglomaceae, with two new genera Archaeospora and Paraglomus, based on cocordant molecular and morphological characters. Mycologia 93: 181-195.

Othira, J.O., Omolo, J.O., Wachira, F.N. and Onek, L.A. 2012. Effectiveness of arbuscular fungi in protection of maize (Zea mays L.) against witchweed (Striga hermonthica Del Benth) infestation. $J$. Agi. Biotech. Sustainable development 4(3): 37-44.

Raju, P.S., Clark, R.B., Duncan, J.R. and Maranville, J.W. 1990. Benefit and cost analysis and phosphorus efficiency of VAM fungi colonization with sorghum genotypes grown at varied phosphorus levels. Plant and Soil, 124:199-204.

Ramakrishnaiah, G. and Vijaya, T. 2013. Influence of VAM fungi, Azotobacter sp. and PSB on soil phosphatase activity and nutrients $(\mathrm{N}, \mathrm{P}, \mathrm{K}, \mathrm{Cu}, \mathrm{Zn}, \mathrm{Fe}$ and $\mathrm{Mn})$ status in the rhizosphere of Stevia rebaudiana (Bert.) plants. Amer. J. Plant Sci. 4: 1443-1447.

Rasouli-Sadaghiani, M., Hassani, A., Barin, M., Rezaee-Danesh, Y. and Sefidkon, F. 2010. Effects of arbuscular mycorrhizal (AM) fungi on growth, essential oil production and nutrients uptake in basil. J. Med. Plants Res. 4: 2222-2228.

Robinson, J.P., Nithya, K., Ramya, R., Karthikbalan, B. and Kripa, K. 2014. Effect of vesicular arbuscular mycorrhiza Glomus fasciculatum on the growth and physiological response in Sesamum indicum L. Intern. Letters Nat. Sci. 23: 47-62.

Ryan, M.H. and Angus, J.F. 2003. Arbuscular mycorrhizae in wheat and field pea crops on a low P soil: increased Zn-uptake but no increase in $\mathrm{P}$ uptake or yield. Plant Soil, 250: 225-239.
Sannazzaro, A.L., Ruiz, A.O., Alberto, E.O. and Menendez, A.B. 2006. Alleviation of salt stress in Lotus glaber by Glomus intraradices. Plant soil, 285: 279-287.

Schenck, N. C. and Perez, Y. 1987. Manual for the identification of VA mycorrhizal fungi. $2^{\text {nd }}$ Ed. INVAM, University of Florida, Gainesville, Florida, USA p 241.

Schenck, N.C and Parez, Y. 1990. Manual for the identification of VA mycorrhizal fungi. INVAM, University of Florida, Gainesville, Florida, USA p 283.

Schubler, A. and Walker, C. 2010. The Glomeromycota: A species list with new families and new genera. The Royal Botanic Garden, Gloucester, England, pp $1-56$.

Sharifi, M., Ghorbanli, M. and Ebrahimzadeh, H. 2007. Improved growth of salinitystressed soybean after inoculation with salt pre-treated mycorrhizal fungi. $J$. Plant Physiol. 164: 1144-1151.

Sharma, D., Kapoor, R. and Bhatnagar, A.R. 2009. Differential growth response of Curculigo orchoides to native AMF communities varying in number and fungal components. Eur. J. Soil Biol. 45: 328-333.

Sharma, S.D., Bhutani, V.P. and Dohroo, N.P. 1998. Occurrence of VAM fungi under old apple orchards. J. Indian Soc. Soil Sci. 46: 143-144.

Sharma, S.D., Sharma, N.C., Sharma, C.L., Kumar, P. and Chandel, A. 2012a. Glomus-Azotobacter symbiosis in apple under reduced inorganic nutrient fertilization for sustainable and economic orcharding enterprise. Sci. Hort. 146: 175-181.

Sharma, S.H.S., Lyons, G., McRoberts, C., McCall, D., Carmichael, E., Andrews, F., Swan, R., McCormack, R. and Mellon, R. 2012b. Biostimulant activity of brown seaweed species from Strangford Lough: Compositional analyses of polysaccharides and bioassay of extracts using mung bean (Vigno mungo L.) and pak choi (Brassica rapa chinensis L.). J. Appl. Phycol. 24: 1081-1091. 
Sharma, S.K., Sharma, G.D. and Mishra, R.R. 1986. Status of mycorrhiza in subtropical ecosystems of Meghalaya. Acta Botanica India, 87-92.

Song, Y., Li, X. and Feng, G. 2001. Effect of VAM fungi on phosphatase activity in maize rhizosphere. Ying Yong Sheng Tai Xue Bao. PubMed. Gov. 12(4): 593-6.

Tabassum, Y., Tanvir, B. and Hussain, F. 2012. Effect of Arbuscular Mycorrhizal inoculation on nutrient uptake, growth and Productivity of chickpea (Cicer arietinum) varieties. Inter. J. Agron. Plant Prod. 3(9): 334-345.

Tabatabai, M.A. and Bremner, J.M. 1969. Use of p-nitrophenol phosphate for assay of soil phosphatase activity. Soil Biol. Biochem. 1: 301-307.

Tadano, T., Ozawa, K., Sakai, H., Osaki, M. and Matsui, H. 1993. Secretion of acid phosphatase by the roots of crop plants under phosphorus-deficient conditions and some properties of the enzyme secreted by lupin roots. Plant and Soil 155/156: 95-98.

Tanvir, B., Farrukh, H. and Sharief, M. 2011. Arbuscular Mycorrhizal Fungi (AMF) Associated with the Rhizosphere of Mentha arvensis L., and M. longifolia HUDS. Pak. J. Bot. 43(6): 3013-3019.

Tian, C., Feng, G., Li, X.L. and Zhang, F.S. 2004. Different effects of arbuscular mycorrhizal fungal isolates from saline or non-saline soil on salinity tolerance of plants. Appl. Soil Ecol. 26: 143-148.

Trindade, A.V., Siqueira, J.O. and Sturmer, S.L. 2006. Arbuscular mycorrhizal fungi in papaya plantations of Espirito Santo and Bahia, Brazil. Braz. J. Micro., 37: 283289.

Utkhede, R.S and Smith, E.M. 2000. Impact of chemical, biological and cultural treatment on the growth and yield of apple in replant disease soil. Aus. Plant Pathol., 29: 129-136.

Veerabhadraswamy, A. L. and Garampalli, R. H. 2011. Effect of arbuscular mycorrhizal fungi in the management of Black Bundle disease of maize caused by Cephalosporium acremonium. Sci. Res. Reporter, 1(2): 96-100.

Wang, F.Y. and Zao, Y.S. 2008. Biodiversity of Arbuscular fungi in China. A review. Adv. Environ. Biol. 2: 31-39.

Wu, Q.S., Srivastava, A.K. and Zou, Y.N. 2013. AMF-induced tolerance to drought stress in citrus: A rev. Sci. Hort., 164: 77-87.

Yan, X., Liao, H., Trull, M.C., Beebe, S.E. and Lynch, J.P. 2001. Induction of a major leaf acid phosphatase does not confer adaptation to low phosphorus availability in common bean. Plant Physiol., 125: 1901-1911.

\section{How to cite this article:}

Baby Summuna, P.A. Sheikh and Tahmina Mushtaq. 2017. Evaluation of Arbuscular Mycorrhizal Fungi of Orchard Soils for Growth Improvement in Maize Under Protected Conditions. Int.J.Curr.Microbiol.App.Sci. 6(3): 1303-1313. doi: https://doi.org/10.20546/ijcmas.2017.603.151 